\title{
IMPLEMENATION OF IAS 16 «PROPERTY, PLANT AND EQUIPMENT» IN ACTIVITY OF ENTITIES OF PUBLIC INTEREST
}

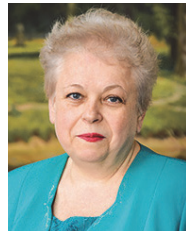

\author{
E.V. KALYUHA, Doctor of Economic Sciences, Professor \\ of the Department of Accounting and Taxation \\ National University of Life and Environmental Sciences \\ of Ukraine
}

ORCID ID: 0000-0001-9057-7476

E-mail: kalyuha.e.v@nubip.edu.ua

\begin{abstract}
Improvement of accounting and financial reporting system is carried out in Ukraine in accordance with the requirements of international standards and legislation of the European Union. There are certain differences in the contents of $A P(S) 7$ «Fixed assets» and IAS 16 "Property, plant and equipment» regarding criteria of recognition of the asset as a fixed asset; its classification, assessment and reassessment; depreciation methods etc.

According to recognition of the asset in international practice there is a probability that future economic benefits will come directly to the entity and professional judgment should be applied during determination of the unit of object in each case.

Classification of fixed assets includes separate classes of vehicles (ships, planes and cars) and tools, instruments and implements (furniture, supplies and office equipment).

Determined types of value of fixed assets: current (recoverable), book value and sales price. There is no residual, net realizable value of a non-current asset.

Reassessment of property, plant and equipment occurs when the residual value of an object substantially differs from its fair value.

The use of the following three methods of depreciation of fixed assets is regulated: straight-line (corresponds to the straight-line method according to AP(S) 7); decrease in residual value (analogue - decrease in residual value); sums of units of production (analog of the manufacturing method). Such two methods of depreciation as cumulative and accelerated reductions in residual values are absent, but other depreciation methods are available and not limited in usage. Implementation of IAS 16 "Property, plant and equipment» by subjects of public interest in Ukraine will allow to switch into international accounting practice.
\end{abstract}

Keywords: fixed assets, unit of object of fixed assets, classification, assessment, reassessment, methods of depreciation, fair value of object, decrease in residual value, subjects of public interest. 


\section{Introduction.}

One of the most important components in the process of creation of material goods by means of enterprises of public interest are fixed assets which are intended for processing of objects of labor in the process of products production. In particular, fixed assets are an important accounting and economic category and object of accounting. It is due to the fact that they hold a significant place in the assets and participate in the formation of the final product. The key to successful agricultural production is the rational use of fixed assets.

Effective management of fixed assets of enterprises of public interest is possible in conditions of existence of effective subsystem of accounting and analytical support. With the development of information technologies, new perspectives on their role in achieving an optimal management system are being refined. Taking into consideration the important role of fixed assets, the problem of assessing the provision, condition and efficiency of their use, as the main prerequisite for making rational and effective management decisions, becomes particularly relevant.

Analysis of recent researches and publications that are devoted to accounting of fixed assets, allows to make the conclusion that this question takes an important place is papers of domestic and foreign economists. In particular, serious attention to this question was payed in papers by Butynets T. A., Butynets F.F., Dombrovska N. R., Zhadan T. A., Zinkevych O. V., Kovalenko O.V., Kuzmin D. L., Matushkina M. P.,
Mordvintseva T. V., Panchuk L. V., Stelmakh Kh.V. and others. However, the studies of these scholars are devoted to accounting of fixed assets according to national standards, while according to the Law "On Accounting and Financial Reporting in Ukraine" entities of public interest must conduct accounting according to international standards.

Scientific, theoretical and practical importance of the problem determined the choice of the theme of the research and identified its main directions.

\section{Purpose.}

The purpose of the research is to make comparison of constituents of national and international accounting standards according to $\mathrm{AP}(\mathrm{S}) 7$ «Fixed assets» and IAS 16 «Property, plant and equipment» regarding economic nature of the category and the ways in which they are recognized; classification, assessment and reassessment of fixed assets; depreciation of fixed assets by public interest entities.

\section{Methods.}

The research is done with the usage of next methods: comparison; grouping; balance method; scientific abstraction; historical and logical, statistical and graphical analysis, etc.

\section{Results.}

The analysis of condition of fixed assets in the agricultural sector of Ukraine (Fig.1) for four years (2015-2018) shows their positive dynamics of receipt, stable

Enterprises - issuers of securities whose securities are admitted to trading on the stock exchanges or in respect of which securities the public offering has been made, banks, insurers, non-state pension funds, other financial institutions (except for other financial institutions and non-state pension funds belonging to micro enterprises and small enterprises) and enterprises that, according to this Law, belong to large enterprises; 
level of disposal, liquidation and accrual of depreciation. But these dynamics is clearly not sufficient for efficient upgrade of fixed assets. Therefore, the provision of positive structural changes and transformations in the agricultural sector at the macro level depends on the process of reproduction of fixed assets, especially in conditions of rapid pace of their physical and moral aging. In order to make grounded management decisions, it is important for each entity to have a necessary level of information regarding the condition, usage and efficiency of reproduction of fixed assets.

Nowadays, among the problems of accounting of fixed assets one must note the lack of unambiguous approaches to their recognition. The most common interpretations of Ukrainian scientists are approaches according to the legislation of Ukraine and ones that are given in international accounting standards. Thus, contemporary economic literature includes a significant number of interpretations of the concept of "fixed assets". At the same time, most author's approaches are derived from the recognition, which is given in $\mathrm{AP}(\mathrm{S}) 7$ «Fixed assets» (hereinafter - AP(S) 7)

The concepts of "fixed assets", which are described in the Tax Code of Ukraine and AP(S) 7 have some differences in the following areas: cost limit; coverage of recognition; term of useful life (the expected period of time during which non-current assets will be used by an agricultural enterprise in order to grow the product).

According to IAS 16 та $\mathrm{AP}(\mathrm{S}) 7$ the most important criterion of recognition of the asset in the capacity of fixed asset is the term of useful life. Also, IAS 16 does not provide any information regarding what must be considered as the unit of fixed assets for accounting. Comparison of criteria of recognition of the asset in the capacity of the fixed asset is presented in Table.1.

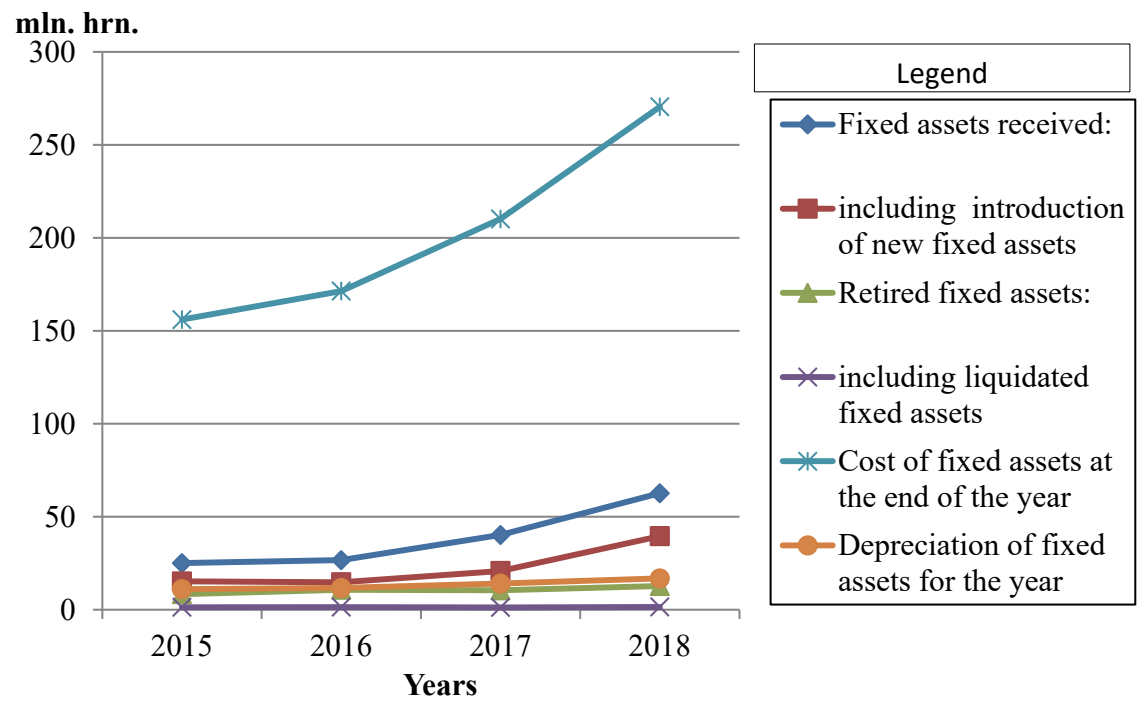

Fig.1 The dynamics of the condition of fixed assets in the agricultural sector of Ukraine ${ }^{2}$

${ }^{2}$ Developped on the basis of the statistical digest / responsible for the edition O.M. Prokopenko. K.: State Statistics Service of Ukraine, 2018. 20- 245 Agriculture of Ukraine 2018 c [7] 
Table 1. Criteria of recognition of the asset in the capacity of the fixed asset

\begin{tabular}{|c|c|c|}
\hline № & AP(S) 7 «Fixed assets» & IAS 16 «Property, plant and equipment» \\
\hline 1 & 2 & 3 \\
\hline 1. & $\begin{array}{l}\text { There is a probability that the } \\
\text { enterprise / institution will benefit } \\
\text { economically from its usage in the } \\
\text { future. }\end{array}$ & $\begin{array}{l}\text { There is a probability that the entity will get } \\
\text { the future economic benefits, associated with } \\
\text { the object. }\end{array}$ \\
\hline 2. & $\begin{array}{l}\text { Its purpose is to be used for the needs } \\
\text { of production or supply of goods, } \\
\text { provision of services, renting out to } \\
\text { others or conduction of administrative } \\
\text { and socio - cultural functions. }\end{array}$ & $\begin{array}{l}\text { It will be used in the production process or in } \\
\text { the supply of goods or services, for rent or for } \\
\text { administrative purposes. }\end{array}$ \\
\hline 3. & $\begin{array}{l}\text { The term of useful life (longer than } \\
\text { one year or operational cycle if it is } \\
\text { longer than one year). }\end{array}$ & $\begin{array}{c}\text { The term of usage - longer than one reporting } \\
\text { period. }\end{array}$ \\
\hline 4. & $\begin{array}{l}\text { The cost of the object can be can be } \\
\text { reliably determined. }\end{array}$ & $\begin{array}{l}\text { The prime cost of the object can be reliably } \\
\text { assessed. }\end{array}$ \\
\hline 5. & $\begin{array}{l}\text { The accounting unit is an item of } \\
\text { fixed assets - a complete device } \\
\text { with all its accessories, or a separate } \\
\text { structural object designed to perform } \\
\text { certain independent functions. }\end{array}$ & $\begin{array}{l}\text { IAS } 16 \text { doesn t define what must be } \\
\text { recognized as accounting unit for the } \\
\text { accounting purposes. That is, the enterprise } \\
\text { must use professional judgment in order } \\
\text { to determine in each case what to consider } \\
\text { as an accounting unit of fixed assets - an } \\
\text { individual object, its component or a group of } \\
\text { homogeneous objects. }\end{array}$ \\
\hline
\end{tabular}

That is, fixed assets are the basis of production resources of the enterprise. Therefore, effective management of these assets is the key to a continuous process of production and sale of products.

Classification, assessment and reassessment of fixed assets. One of the methods of cognition, research, study of objects and phenomena is classification (Table 2), that is, division into classes based on certain general features of the objects, patterns and relationships between them.

The essence of the concept "classification" defines it as a system of distribution of objects (processes, phenomena) by classes, groups, according to certain characteristics. The scientifically grounded classification of fixed assets allows to obtain detailed management information on their optimal condition, structure, needs and sources of forma- tion, as well as to properly organize accounting. In turn, this opens up opportunities for the rational management of fixed assets that will help to increase the economic efficiency of the public interest enterprise.

There are some differences in approaches to classification of fixed assets according to international and national accounting standards.

The grouping of fixed assets according to IAS 16 and $\mathrm{AP}(\mathrm{S}) 7$ is different because of a number of reasons. Namely, IAS 16 separately identifies groups such as ships, planes and cars. In turn, AP(S) 7 contains larger group - vehicles, which includes these classes according to IAS 16. Also, IAS 16 identifies individual classes of furniture and accessories and office equipment.

According to p. 15 of IAS 16, an object of fixed assets that meets the 
Table 2. Classification of fixed assets

\begin{tabular}{|l|c|c|}
\hline Classification of fixed assets & AP(S) 7 «Fixed assets» & $\begin{array}{c}\text { IAS 16 «Property, plant } \\
\text { and equipment» }\end{array}$ \\
\hline Land plots & + & + \\
\hline $\begin{array}{l}\text { Capital expenditures for land } \\
\text { improvement }\end{array}$ & + & - \\
\hline Buildings & + & + \\
\hline $\begin{array}{l}\text { Constructions and transmitting } \\
\text { devices }\end{array}$ & + & + \\
\hline Machines and equipment & + & + \\
\hline Vehicles & + & $\begin{array}{c}\text { There are separate classes: } \\
\text { 1) ships 2) planes 3) cars }\end{array}$ \\
\hline Instruments & + & $\begin{array}{c}\text { 1) furniture and } \\
\text { accessories }\end{array}$ \\
\hline Devices & + & \begin{tabular}{c} 
2) office equipment \\
\hline Inventory (furniture)
\end{tabular} \\
\hline Animals & + & - \\
\hline $\begin{array}{l}\text { Perennial plantings and other fixed } \\
\text { assets }\end{array}$ & + & - \\
\hline
\end{tabular}

above-mentioned conditions is assessed by costs. In accordance with p. 29-31 of IAS 16, a public interest entity should fix in accounting policy one of two accounting models: the cost model - according to which an object is assessed at residual value (historical cost minus accumulated depreciation and minus accumulated impairment losses); the reas- sessment model - the assessment is done at fair value at the date of reassessment minus accumulated depreciation and accumulated impairment losses.

The procedure of formation of assessment of fixed assets depends on the events that caused their arrival at the enterprise. Basing on the conducted analysis, it can be concluded that a signifi-

\section{Table 3. Cost of fixed assets and their types}

\begin{tabular}{|l|c|c|}
\hline Cost & $\mathrm{AP}(\mathrm{S}) 7$ «Fixed assets» & $\begin{array}{c}\text { IAS 16 «Property, plant } \\
\text { and equipment» }\end{array}$ \\
\hline Initial & + & + \\
\hline Fair & + & + \\
\hline Reassessed & + & + \\
\hline $\begin{array}{l}\text { Net value of realization of a non- } \\
\text { current asset }\end{array}$ & + & + \\
\hline Depreciable cost & + & + \\
\hline Liquidation & + & - \\
\hline Residual & + & + \\
\hline Current or restorative & - & + \\
\hline Balance & - & + \\
\hline Possible selling price & - & + \\
\hline
\end{tabular}


cant feature of the valuation of property, plant and equipment under IFRS is the ability to reduce the carrying amount of relevant government grants, which is not provided for by a national standard. Basing on the conducted analysis one can conclude that a significant feature of fixed assets assessment according to IAS is the ability to reduce the balance value by means of relevant state grants. This opportunity is not provided by the national standard.

In general, comparison of methodology of accounting of fixed assets according to national and international standards (Table 3) allows to make a conclusion that they are similar in major aspects of accounting, but some differences are observed in terms of assessment, reassessment, recognition of initial cost, depreciation and disposal.

That is, the national standard does not include types of values that exist in international market, namely: current, balance and possible selling price. There are some differences in cost approaches that are included in the cost of fixed assets according to international and national accounting standards (Table 4).

The analysis shows that, for example, according to IAS 16 costs does not include the amount of import charge,

\section{Table 4. Cost structure according to AP(S) 7 «Fixed assets» and IAS 16 «Property, plant and equipment» that are included to initial cost}

\begin{tabular}{|c|c|c|}
\hline № & AP(S) 7 «Fixed assets» & IAS 16 «Property, plant and equipment» \\
\hline 1 & 2 & 3 \\
\hline 1. & $\begin{array}{l}\text { Amounts paid to asset suppliers and } \\
\text { contractors for construction work } \\
\text { (excluding indirect taxes). }\end{array}$ & $\begin{array}{l}\text { Purchase prices, including import charges } \\
\text { and recompensed purchase taxes after } \\
\text { exclusion of trade and price discounts. }\end{array}$ \\
\hline 2. & $\begin{array}{l}\text { Registration fees, state charges and similar } \\
\text { payments in connection with acquisition } \\
\text { of rights for the object of the fixed asset. }\end{array}$ & - \\
\hline 3. & The amount of import charge & - \\
\hline 4. & $\begin{array}{c}\text { Amounts of indirect taxes in connection } \\
\text { with acquisition or creation of fixed assets } \\
\text { (provided that they are not recompensed } \\
\text { to the enterprise). }\end{array}$ & - \\
\hline 5. & $\begin{array}{l}\text { Costs for insurance of risks of delivery of } \\
\text { fixed assets }\end{array}$ & $\begin{array}{c}\text { Any costs directly attributed to delivering } \\
\text { the asset to its location and bringing it } \\
\text { to the condition that is necessary for its } \\
\text { operation in a manner, which is determined } \\
\text { by management. }\end{array}$ \\
\hline 6. & $\begin{array}{l}\text { Costs for transportation, installation, } \\
\text { adjustment of fixed assets. }\end{array}$ & - \\
\hline 7. & $\begin{array}{l}\text { Other costs that are directly attributable to } \\
\text { bringing the fixed assets to a condition in } \\
\text { which they fit for usage for the intended } \\
\text { purpose. }\end{array}$ & $\begin{array}{l}\text { Initial preliminary assessment of the cost } \\
\text { for dismantling, removing the object and } \\
\text { rebuilding the territory at which it is located, } \\
\text { the obligation according to which the public } \\
\text { interest entity incurs or when purchases } \\
\text { this object, or when using it for a certain } \\
\text { period for the purpose which differs from } \\
\text { production of inventories during this period. }\end{array}$ \\
\hline
\end{tabular}


the amount of indirect taxes in connection with acquisition or creation of fixed assets, transportation, installation, adjustment of fixed assets.

Reassessment of fixed assets is carried out under the conditions specified in p. 16 of $\mathrm{AP}(\mathrm{S})$ 7, namely, in case of a significant deviation of the residual value of the object from its fair value. The main reasons for this deviation may be: the difference between physical deterioration in the process of operation activity and deterioration due to depreciation; moral deterioration; change in market prices for fixed assets due to inflation. The reassessment algorithm is presented in Fig.2.

The criterion of materiality of the deviation for reassessment is defined in p.17 of the accounting policy order, which is $10 \%$ of the residual value of accounting objects from their fair value. The reassessment is done on the annual balance sheet date. That is at the end of the calendar year. When performing a reassessment of the object of fixed asset at the same date, all objects of the group to which that object belongs are being reassessed - for example, when the car is reassessed, all objects of the group "Vehicle" are reassessed. Groups of fixed assets which objects were reassessed must be reassessed every three years to ensure that their residual value does not differ from their fair value at the balance sheet date.

The basis for the reassessment of fixed assets is determination of the fair value of the objects. In order to do this, enterprises of public interest use the services of certified professional valuers. The result of the conducted assessment is confirmed by the prepared Asset Valuation Report (act of asset valuation), which contains the valuer's opinion on the fair (market) value of the fixed asset and confirms the valuation procedures performed.

Reassessment of objects of fixed assets with zero residual value is done in accordance with the paragraph 17 of $\mathrm{AP}(\mathrm{S}) 7$ : the reassessed residual value is determined by adding the fair value of this object to its original (reassessed) val-

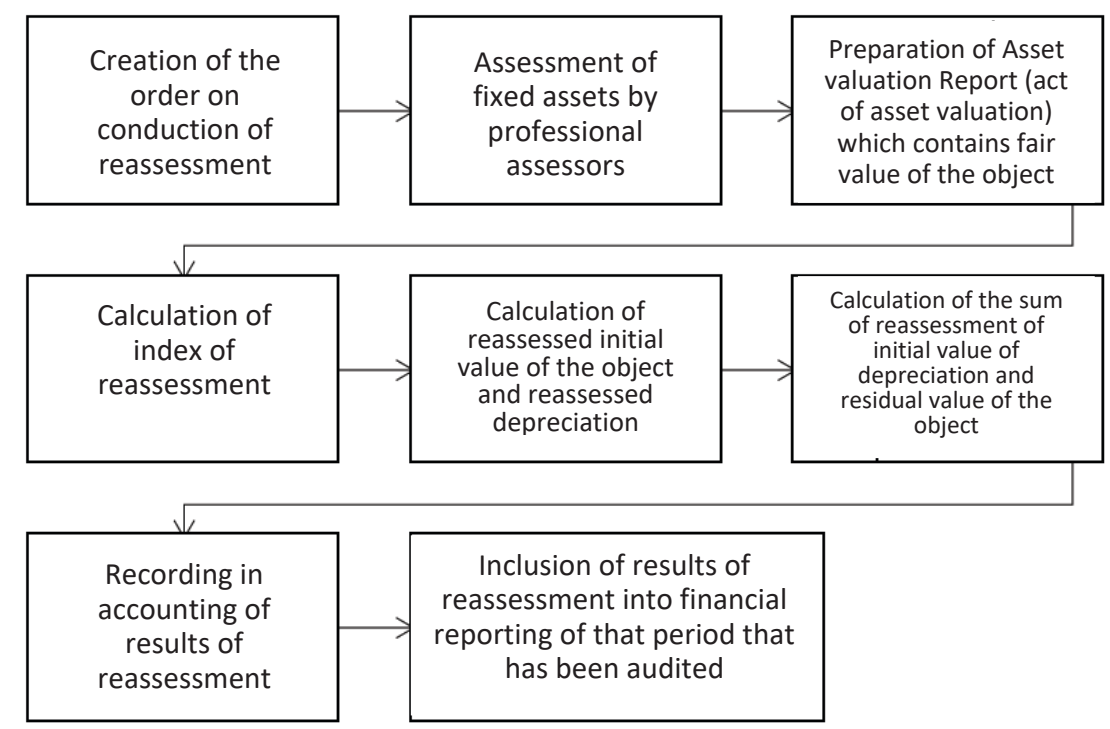

Fig.2. The algorithm of reassessment of fixed assets 
ue; the amount of depreciation of the fixed asset - remains unchanged; the liquidation value is determined (for the objects of fixed assets that continue to be used).

The reassessment of fixed assets is aimed at the objectivity and reliability of reflecting the value of fixed assets in the financial statements and avoiding distortions of accounting information, which grounds the importance of its fair conduction.

\section{Depreciation of fixed assets.}

During operation, fixed assets are deteriorated and lose their original characteristics due to physical (degradation of technical and economic parameters, decrease in productivity due to aging) and moral deterioration (due to the creation of newer and more productive means of production). The transfer of value of fixed assets to the finished product is done by means of depreciation - in accordance with $p .4$ of AP(S) 7 it is a systematic distribution of the value of depreciable fixed assets during their useful life. The concept of depreciation and deterioration of fixed assets are not identical. Depreciation is a subjective phenomenon, since the entity makes its own decisions about the method of calculating depreciation. The definition of depreciation in IAS 16 is given in p. 6 of the standard, according to which depreciation is the systematic distribution of the amount of depreciable asset over its useful life. The advantages and disadvantages of depreciation methods in accordance with AP(S) 7 and IAS 16 are shown in table 5 .

The conducted research testifies that usually in practical work the straightline method is applied. Its algorithm is as follows: the annual amount of depreciation is determined by means of dividing the value of the object of the fixed asset on the term of its useful life; the monthly depreciation amount is determined by means of dividing the annual depreciation amount on 12 (the number of months in the year).

Accounting of depreciation in software environment 1C: Accounting 2.0 is done by means of the usage of the document "Depreciation", which automatically forms debit of cost accounts, and the credit of the account 13 "Depreciation of fixed assets" for each object of fixed assets and calculates the amounts of depreciation. The document also controls the residual value of each inventory object.

The straight-line depreciation method has the advantage of being easy to apply because the depreciable cost is evenly distributed over the useful life of the object of fixed assets. However, this is also a significant disadvantage of this method, since the economic effect of using an object of fixed assets is usually not evenly - especially for the active part of fixed assets (vehicles, equipment, cars) - the last years of usage bring less effect, while operation costs for repair and maintenance increase.

\section{Discussion.}

The definition of the category "fixed assets" in the Tax Code of Ukraine and $\mathrm{AP}(\mathrm{S}) 7$ has some differences in the following areas: cost limit; coverage of the recognition; term useful life.

According to IAS 16, an entity should choose one of two accounting models in accounting policy:

the cost model - according to which an object is assessed at residual value (historical cost minus accumulated depreciation and minus accumulated impairment losses);

the reassessment model - the assessment is done at fair value at the date of 


\section{Table 5. Comparative characteristics of depreciation: advantages and disadvantages}

\begin{tabular}{|c|c|c|}
\hline \multicolumn{3}{|c|}{$\begin{array}{l}\text { Regulated methods of depreciation of fixed assets in accordance with } \\
\qquad \text { AP(S) } 7 \text { and IAS 16: }\end{array}$} \\
\hline 1. & Straight-line & Straight-line \\
\hline \multicolumn{3}{|c|}{ Advantages: } \\
\hline \multicolumn{3}{|c|}{ Easy to calculate, predictable amount of accumulated deterioration } \\
\hline \multicolumn{3}{|c|}{ Disadvantages: } \\
\hline \multicolumn{3}{|c|}{$\begin{array}{l}\text { The features of moral deterioration are not taken into account. The depreciation amount } \\
\text { does not depend on the volume of production. It does not allow to calculate the real cost }\end{array}$} \\
\hline 2. & Decrease in residual value & Residue reduction \\
\hline \multicolumn{3}{|c|}{ Advantages: } \\
\hline \multicolumn{3}{|c|}{$\begin{array}{l}\text { Rapid accumulation of deterioration in first periods of usage of fixed assets. This is justified } \\
\text { in conditions of the usage of modern computer technology that is influenced more rather } \\
\text { with moral obsolescence than physical. }\end{array}$} \\
\hline \multicolumn{3}{|c|}{ Disadvantages: } \\
\hline \multicolumn{3}{|c|}{$\begin{array}{l}\text { Complexity of calculation; liquidation value of fixed assets cannot be zero. During first } \\
\text { years of application the cost of production (goods, works, services) is overstated. }\end{array}$} \\
\hline \multicolumn{3}{|c|}{$\begin{array}{l}\text { Regulated methods of depreciation of fixed assets in accordance with } \\
\qquad \mathrm{AP}(\mathrm{S}) 7 \text { and IAS 16: }\end{array}$} \\
\hline 3. & Accelerated reduction in residual value & - \\
\hline \multicolumn{3}{|c|}{ Advantages: } \\
\hline \multicolumn{2}{|c|}{$\begin{array}{l}\text { Peculiarities of moral deterioration are taken } \\
\text { into account. }\end{array}$} & - \\
\hline \multicolumn{3}{|c|}{ Disadvantages: } \\
\hline \multicolumn{2}{|c|}{$\begin{array}{l}\text { Uneven distribution of depreciation amounts } \\
\text { over periods of use. }\end{array}$} & - \\
\hline 4. & Cumulative & - \\
\hline \multicolumn{3}{|c|}{ Advantages: } \\
\hline \multicolumn{2}{|c|}{$\begin{array}{l}\text { Predictable and planned accumulation of } \\
\text { depreciation amounts. }\end{array}$} & - \\
\hline \multicolumn{3}{|c|}{ Disadvantages: } \\
\hline \multicolumn{2}{|c|}{$\begin{array}{l}\text { Difficult for practical use: the depreciation } \\
\text { amount does not depend on the volume of } \\
\text { production, which does not allow you to } \\
\text { calculate the real cost. }\end{array}$} & - \\
\hline 5. & Manufacturing & The method of sums of units of production \\
\hline \multicolumn{3}{|c|}{ Advantages: } \\
\hline \multicolumn{3}{|c|}{$\begin{array}{l}\text { Allows to determine the specific participation of fixed assets in production and to make } \\
\text { clear transfer of part of their value to the cost of produced product }\end{array}$} \\
\hline \multicolumn{3}{|c|}{ Disadvantages: } \\
\hline & $\begin{array}{l}\text { oreciation is not predictable, it is difficult } \\
\text { determine the production capacity of }\end{array}$ & $\begin{array}{l}\text { o plan, because it is not always possible to } \\
\text { an object throughout its useful life. }\end{array}$ \\
\hline
\end{tabular}

reassessment minus accumulated depreciation and accumulated impairment losses.
When comparing fixed assets according to national and international standards, one can conclude that there 
are some differences in assessment, reassessment, recognition of initial cost, depreciation and disposal. The International Accounting Standard has a general advisory nature and does not take into account the national peculiarities of accounting in Ukraine.

Conduction of reassessment of fixed assets takes place when the residual value of an object substantially differs from its fair value. The main reasons for this deviation may be: the difference between physical deterioration in the process of operation activity and deterioration due to depreciation; moral deterioration; change in market prices for fixed assets due to inflation.

The basis for the reassessment of fixed assets is determination of the fair value of the objects.

According to $\mathrm{AP}(\mathrm{S}) 7$ there are five depreciation methods that have certain advantages and disadvantages. In turn, according to international standard there are three methods of depreciation - straight-line method, method of residue reduction and method of sums of units of production.

There are a number of entities in Ukraine that were identified as ones that must prepare financial and consolidated financial statements for 2018 according to international standards. Therefore, there is the need for transformation of financial statements prepared in 2018 into statements prepared according to IFRS. The essence of the last one is to bring balances on the beginning of the transition to IFRS in full compliance with the rules set by national accounting standards; to choose accounting policy under IFRS; to assess assets and liabilities in accordance with the criteria for recognition and transformation of the balance sheet; to define deferred taxes related to the adjustment of assets and liabilities; to complete three accounting documents: a journal of adjustments, adjustment records and a transformation table.

The defined methodology of transformation of accounting information will allow to disclose information in accounting in accordance with international practice in objective and accurate way.

\section{References}

1. Lozotska K.S., Kaliuha E.V. «Accounting and assessment of fixed assets according to international standards" / Collection of materials of 72 th scientific and practical student conference: "Conceptual principles of balanced development of the agrarian sector of the Ukrainian economy», 01.12.2017, NULES. Kyiv, abstracts P.150-151.

2. Lozotska K.S., Kaliuha E.V. «Comparative characteristics of depreciation according to AP(S) 7 and IAS 16. Collection of materials of 72 th scientific and practical student conference: «Conceptual principles of balanced development of the agrarian sector of the Ukrainian economy», 21.11.2018, NULES. Kyiv, abstracts - P.183-186

3. Kalyuga E. V., Lozotska K.S. Selection of the optimum method of amortization for industrial enterprises. 1st International Scientific and Practical Conference: «IMPERATIVES OF CIVIL SOCIETY DEVELOPMENT IN PROMOTING NATIONAL COMPETITIVENESS», December 13-14, 2018, Batumi navigation teaching university, Batumi, Georgia, 139-141

4. Lozotska K.S., Kaliuha E.V. «Directions of updating of classification of fixed assets in accounting under the influence of the development of technology». Collection of scientific papers: «Accounting, analysis and audit: problems of theory, methodology, organization", 30.11.2017, National academy of statistics, accounting and audit, Kyiv, article - P.35- 45 
5. Lozotska K.S., Kaliuha E.V. «Financial reporting as the source of information for making management decisions». Collection of IX international scientific and practical conference: «Modern problems and perspectives of the development of accounting, analysis and control in conditions of globalization of economics», 02.12.2017 , LNTU, Lutsk, article - P. $121-127$.
6. International Accounting Standard 16 (IAS 16). Property, plant and equipment. // IASB; Standard, International document of 01.01.2012. [Electronic resource] - Access mode: http:// zakon2.rada.gov.ua/laws/show/929_014

7. Agriculture of Ukraine 2017: statistical collection / responsible for edition O.M. Prokopenko. K.: State Statistics Service of Ukraine, 2018. 20- 245 p.

\section{Е.В.КаЛюга (2019). ВНЕДРЕНИЕ МСБО 16 «ОСНОВНЫЕ СРЕДСТВА» В ДЕЯТЕЛЬНОСТЬ СУБЪЕКТОВ ОБЩЕСТВЕННОГО ИНТЕРЕСА.БІОЕКОНО- НОМІКА ТА АГРАРНИЙ БІЗНЕС, 10(2): 52-63. http://doi.org//10.31548/ bioeconomy2019.02.52.}

Анотация. Совершенствование системы бухгалтерского учета и финансовой отчетности осуществляется в Украине с учетом требований международных стандартов и законодательства Европейского Союза. Существуют отдельные различия в содержании стандартов П(С) БО 7 «Основні засоби» И М(С) БО 16 «Основные средства» при : определении критериев отнесения актива к основным средством, его классификации, оценки и переоценки; применении методов начислении амортизации. В соответствии с признанием актива в международной практики имеется вероятность того что будущие экономические выгоды поступят непосредственно к субъкту хозяйствования , ,при определении единицы объекта в каждом конкретном случае должно применяться професиональное суджение.

Класификация основних средств предусматривает выделение отдельных классов транспортных средств (корабли, самолеты и автомобили) и инструментов, приспособлений и инвентаря (мебли, приспособления и офисное оборудование).

Определены виды стоимости основных средств: текущая(восстановительная), балансовая и возможная цена продажи, не предусмотреные - остаточная, чистая стоимость реализации необоротного актива.

Проведение переоценки основных средств осуществляется при существенной разнице остаточной стоимости объекта от его справедливой.

Регламентировано использование следующих трьох методов амортизации основных средств: прямолинейного (соответствует прямолинейному методу по П(С)БО 7); уменьшения остаточной стоимости (аналог - уменьшения остаточной стоимостиі; сумы единицы продукции (аналог - производственного метода).Отсутствуют два метода начисления амортизации: кумулятивный и ускорение уменьшения остаточной стоимости ,но не ограничены возможности в применении других методов амортизации. Внедрение $M(C)$ БО 16 «Основные средства» субъектами общественного интереса в Украине предоставит возможность перейти на международную практику ведения бухгалтерского учета.

Ключевые слова: основные средства, единица объекта основных средств, класификация, оценка, переоценка, методы начисления амортизації, справедливая стоимость объекта, уменьшение остаточной стоимости, субъекты общественного интереса. 


\section{Є.В.Калюга (2019). ВПРОВАДЖЕННЯ МСБО 16 «ОСНОВНІ ЗАСОБИ»}

В ДІЯЛЬНІСТЬ СУБ'ЄКТІВ СУСПІЛЬНОГО ІНТЕРЕСУ. БІОЕКОНОНОМІКА ТА АГРАРНИЙ

БІЗНЕC, 10(2): 52-63. http://doi.org//10.31548/bioeconomy2019.02.052.

Анотація. Удосконалення системи бухгалтерського обліку та фінансової звітності здійснюється в Україні з урахуванням вимог міжнародних стандартів та законодавства Європейського Союзу. Існуютьпевні розбіжностів змістістандартів П(С) БО 7 «Основнізасоби» та М(C) БО 16 «Основні засоби» при : визначенні критеріїв визнання активу основним засобом ; його класифікації, оцінки і переоцінки; застосування методів нарахування амортизації тощо.

Відповідно до визнання активу в міжнародній практиці $\epsilon$ ймовірність того, що майбутні економічні вигоди, надійдуть безпосередньо до суб'єкта господарювання, при визначенні одиниці об'єкта в кожному конкретному випадку повинно застосовуватися професійне судження.

Класифрікація основних засобів передбачає виділення окремих класів транспортних засобів (кораблі, літаки та автомобілі) та інструментів, приладів і інвентаря (меблі, приладдя та офісне обладнання).

Визначені види вартості основних засобів: поточна (відновна), балансова та можлива ціна продажу, не передбачена - залишкова, чиста вартість реалізації необоротного активу.

Проведення переоцінки основних засобів відбувається при істотному відхиленні залишкової вартості об'єкта від його справедливої.

Регламентовано використання наступних трьох методів амортизації основних засобів: прямолінійного (відповідає прямолінійному методу за П(С)БО 7); зменшення залишкової вартості (аналог - зменшення залишкової вартості); суми одиниць продукції (аналог виробничого методу).Відсутні два методи нарахування амортизації :кумулятивний та прискорений зменшення залишкової вартості, але не обмежені можливі в застосовувані інших методів амортизації. Впровадження М(C) БО 16 «Основні засоби» суб'єктами суспільного інтересу в Україні надасть можливість перейти на міжнародну практику ведення бухгалтерського обліку.

Ключові слова: основні засоби, одиниця об'єкта основних засобів, класифікація, оцінка, переоцінка, методи нарахування амортизації, справедлива вартість об'єкта, зменшення залишкової вартості, суб'єкти суспільного інтересу. 